AUTHOR CORRECTION OPEN

\title{
Author Correction: The potential role of land cover on secular changes of the hydroclimate of Peninsular Florida
}

Vasubandhu Misra ${ }^{1,2,3}$, Akhilesh Mishra ${ }^{1,4}$, Amit Bhardwaj $\mathbb{D}^{1,3}$, Krishnan Viswanathan ${ }^{5}$ and Dan Schmutz (D)

npj Climate and Atmospheric Science (2018)1:15; doi:10.1038/s41612-018-0024-x

Correction to: npj Climate and Atmospheric Science https://doi.org/ 10.1038/s41612-018-0016-x, Published online 9 April 2018

One of the author names was misspelled. This has now been corrected in the HTML and PDF versions of this article.

Open Access This article is licensed under a Creative Commons Attribution 4.0 International License, which permits use, sharing, adaptation, distribution and reproduction in any medium or format, as long as you give appropriate credit to the original author(s) and the source, provide a link to the Creative
Commons license, and indicate if changes were made. The images or other third party material in this article are included in the article's Creative Commons license, unless indicated otherwise in a credit line to the material. If material is not included in the article's Creative Commons license and your intended use is not permitted by statutory regulation or exceeds the permitted use, you will need to obtain permission directly from the copyright holder. To view a copy of this license, visit http://creativecommons. org/licenses/by/4.0/.

(c) The Author(s) 2018

${ }^{1}$ Center for Ocean-Atmospheric Prediction Studies, Florida State University, Tallahassee, FL, USA; ${ }^{2}$ Department of Earth, Ocean and Atmospheric Science, Florida State University, Tallahassee, FL, USA; ${ }^{3}$ Florida Climate Institute, Florida State University, Tallahassee, FL, USA; ${ }^{4}$ Amity Center for Ocean-Atmosphere Science and Technology, Amity University, Jaipur, Rajasthan, India; ${ }^{5}$ Cambridge Systematics, Inc, Tallahassee, FL, USA and ${ }^{6}$ Greenman-Pedersen, Inc, Orlando, FL, USA

Correspondence: Vasubandhu Misra (vmisra@fsu.edu)

Published online: 24 May 2018 